\title{
WPS3644
}

\section{The Economic Consequences of Health Shocks}

\author{
Adam Wagstaff \\ Development Research Group and East Asia \& Pacific Region \\ The World Bank, Washington DC, USA
}

World Bank Policy Research Working Paper 3644, June 2005

The Policy Research Working Paper Series disseminates the findings of work in progress to encourage the exchange of ideas about development issues. An objective of the series is to get the findings out quickly, even if the presentations are less than fully polished. The papers carry the names of the authors and should be cited accordingly. The findings, interpretations, and conclusions expressed in this paper are entirely those of the authors. They do not necessarily represent the view of the World Bank, its Executive Directors, or the countries they represent. Policy Research Working Papers are available online at http://econ.worldbank.org.

Author's contact details: The World Bank, Mailstop MC3-306, 1818 H Street NW, Washington, D.C. 20433, USA. Tel. (202) 473-0566. Fax (202)-522 1153. Email: awagstaff@worldbank.org. 


\section{Summary}

While there is a great deal of anecdotal evidence on the economic impacts of adverse health shocks, there is relatively little hard empirical evidence. This paper builds on recent empirical work to explore in the context of post-reform Vietnam two related issues: how far household income and medical care spending respond to health shocks; and how far household consumption is protected against health shocks. The results suggest that adverse health shockscaptured by negative changes in body mass index (BMI)-are associated with reductions in earned income. This appears to be only partly-if at all-due to a reverse feedback from income changes to BMI changes. By contrast, there is a hint-the relevant coefficient is not significant - that adverse BMI shocks may result in increases in unearned income. This may reflect additional gifts, remittances, etc. from family and friends following the health shock. Medical spending is found to increase following an adverse health shock, but not among those with health insurance. The impact for the uninsured is large, equal in absolute size to the income loss associated with a BMI shock. The lack of impact for the insured points to complete insurance against the medical care costs associated with health shocks, and is consistent with the very generous coverage of Vietnam's health insurance program at this time (1993-98). The question arises: have Vietnamese households been able to hold their food and non-food consumption constant in the face of these income reductions and extra medical care outlays? The results suggest not. For the sample as a whole, both food and non-food consumption are found to be responsive to health shocks, indicating an inability to smooth non-medical consumption in the face of health shocks. Further analysis reveals some interesting differences across different groups within the sample. Households with insurance come no closer to smoothing non-medical consumption than uninsured households. Furthermore, and somewhat counterintuitively, better-off households_-including insured households-fare worse than poorer households in smoothing their non-medical consumption in the face of health shocks, despite the fact that in the case of insured households there are no medical bills associated with an adverse health event. Why the poor rely on dissaving and borrowing to such an extent, and do not apparently reduce their food and non-food consumption following an adverse health shock while the better off do, may be because the levels of food and non-food consumption of the poor are simply too low relative to basic needs to enable them to cut back in the face of an adverse BMI shock.

Keywords: health shocks; consumption smoothing; insurance. 


\section{INTRODUCTION}

Anecdotal evidence on the economic impacts of adverse health shocks abounds. An Egyptian woman in a recent global participatory poverty study known as Voices of the Poor reported "We face a calamity when my husband gets ill. Our life comes to a halt until he recovers and goes back to work." (Narayan, Patel et al. 2000). The same study recorded the case of a 26 year-old man in Lao Cai, Vietnam, who, as a result of the large health care costs necessitated by his daughter's severe illness, moved from being the richest man in his community to being one of the poorest. Also recorded were the remarks of a Vietnamese woman from Tra Vinh who said "Poor people cannot improve their health status because they live day by day, and if they get sick they are in trouble because they have to borrow money and pay interest."

While there is no shortage of anecdotal evidence, firm empirical evidence on the economic consequences of health shocks is harder to come by. This paper builds on two recent papers (Dercon and Krishnan 2000; Gertler and Gruber 2002) to explore two related issues: how far household income and medical care spending responds to health shocks; and how far household consumption is protected against health shocks.

The extent to which household income responds to health shocks depends on a number of factors. One is the extent to which households rely on one or two members for their income. The income of an urban household with a single breadwinner may not be affected at all when household members other than the breadwinner falls sick, but is especially vulnerable when the breadwinner falls ill. A rural household with many household members-including childrencontributing to the household's income is less vulnerable when, say, the household head falls sick, and may even be able to reallocate labor time to compensate for lost income. Both types of household may see any losses in earned income associated with illness offset at least in part by increases in unearned income. This could involve payments to cover lost wages by a formal sickness insurance scheme. Or it might involve informal payments by relatives or friends in the form of extra remittances or gifts intended to help cover lost income and medical expenses. It is plausible that the size of any informal payments could depend on whether the household has access to other forms of assistance or insurance-a household that is already covered by formal sickness and health insurance schemes is unlikely to be considered especially needy by relatives and friends. Evidence on the differential impacts across different household types of health shocks on earned and unearned income is scant-this paper presents new evidence on the subject.

The degree to which medical care spending responds to health shocks is likely to depend largely on whether the household — or the affected member of the household-has formal health insurance, or is covered by a fee-waiver program. But even households with health insurance may see medical outlays rise in response to health shocks. An obvious reason is their coverage may be limited - they may not be covered for outpatient expenses or for drug costs, or there may be a ceiling on reimbursements. Less obviously, providers and patients alike may increase utilization once the patient is covered (more diagnostic tests, more expensive medication, etc.), so that a patient's outlays following a health shock may be little different with and without 
insurance. Evidence on this issue is also limited, especially on the question of whether the medical outlays of people with insurance are less responsive to health shocks.

The impacts of health shocks on income and medical spending reveal nothing about the impacts of health shocks on household (non-medical) consumption. It is, however, a widely held view that health shocks reduce incomes and raise medical spending to such an extent that household consumption is often considerably affected, and may force levels of food consumption of near-poor households below the amount required to maintain a target calorie intake. There is very little hard evidence on the subject, however. Yet this-and the issue of whether people experiencing health shocks receive appropriate medical care-is a key issue. Policymakers presumably would not be particularly worried if, through one means or another, households are able to protect their consumption following a health shock, despite suffering an income loss and spending more on medical care.

The obvious means by which consumption would be smoothed in the face of healthrelated income shocks and medical spending shocks would be through saving and borrowing. The evidence to date suggests that households - especially poor ones - are not able to smooth or insure against income shocks completely ${ }^{1}$, suggesting that income changes resulting from health shocks are likely to be passed through into consumption changes. It may, however, be that income shocks stemming from health shocks may be easier or more difficult to insure against than other types of income shock. Informal credit may be easier to obtain insofar as relatives and friends might look more favorably on a request for a loan following a health shock than they would after a shock of other some type, especially if they thought the household were to blame for the income change. Formal credit, by contrast, may be harder to get, since there is no collateral involved, and since the effectiveness of medical care is subject to a high degree of uncertainty, health investments might be considered too risky by lending institutions. It may therefore be dangerous to assess the ability of households to insure consumption against health shocks indirectly by coupling estimates of the responsiveness of income to health shocks with estimates of the responsiveness of consumption to income shocks. This paper presents direct evidence on the impacts of health shocks on consumption, reporting separate results for food consumption and non-food consumption.

\section{SETTING, METHODS AND DATA}

\section{The Setting}

The setting for the analysis is Vietnam during the period 1993-98. Prior to the Doi Moi (or 'renovation') reforms of the late 1980s, health services in Vietnam were provided at the taxpayer's expense, with patients paying only the cost of drugs (Bloom 1998). With the decollectivization of agriculture and the liberalization of the economy, the role of government in health finance was reduced dramatically. Since 1989 government facilities have been allowed to charge fees, and in 1991 legislation was passed that paved the way for a private health sector (Bloom 1998; Glewwe 2003). Household out-of-pocket spending on health care has, as a result, risen dramatically, accounting for 80\% of total health spending in 1998 (World_Bank, SIDA et

\footnotetext{
${ }^{1}$ See, for example, Townsend (1994; Townsend 1995), Jalan and Ravallion (1999), Gertler and Gruber (2002) and Blundell et al. (2004).
} 
al. 2001). Tales of hardship caused by out-of-pocket health care payments abound, and survey data appear to be consistent with this. In 1998, 7\% of an average Vietnamese household's total consumption was absorbed by health care spending (World_Bank, SIDA et al. 2001), and in the same year one-fifth of the population spent in excess of $20 \%$ of their non-food consumption on health care (Wagstaff and van Doorslaer 2003). In 1998, a single visit to a public hospital by someone from the bottom quintile cost the equivalent of $22 \%$ of their annual non-food consumption (World_Bank, SIDA et al. 2001).

During the period in question, the government had three broad measures to reduce the cost of health care at the point of use. First, in 1994 it assumed the responsibility of paying employees in commune health centers, which in the pre-reform system had been the responsibility of communes (Glewwe 2003). Fees to commune health centers were as a result of this change supposed to be non-existent, and in practice the vast majority of people (82\% according to one estimate) did not pay fees for commune health center visits in this period (World_Bank, SIDA et al. 2001). Second, a patchwork system of fee exemptions was developed, oriented almost exclusively towards the cost of hospital care. This was intended to be targeted towards the poor. However, in practice the better off have benefited almost as much as the poor, though the targeting appears to have improved between 1993 and 1998 (World_Bank, SIDA et al. 2001). Third, the government introduced a health insurance scheme in 1993, known initially as Vietnam Health Insurance (VHI). Civil servants, state enterprise workers, the military and Communist party officials are all covered at the government's expense, and private firms with more than 10 employees were and still are required to enroll their workers. A voluntary component of the program exists, but official records show that voluntary enrolment has remained very low to date, and that those enrolled voluntarily tend to be school children who are typically enrolled en masse by their school, with the children's parents paying the cost of the contribution. Coverage is much less generous for the voluntarily enrolled. Insurance coverage is concentrated fairly heavily among the better off.

In addition—subject to the policies outlined in the previous paragraph—-to making outof-pocket medical expenditures more sensitive to health shocks, the Doi Moi reforms are also likely to have raised the impact of health shocks on household income. The reforms aimed explicitly at replacing the planned economy by a regulated market economy. The decollectivization of agriculture made for a far closer link between a household's income and its agricultural output. In industry, state-owned enterprises (SOEs) were either downsized or closed, with a third of SOE employees losing their job between 1989 and 1992 (Glewwe 2003). The private sector grew rapidly to fill the void, but the likely effect of these changes is that the link between a worker's wages and his or her productivity-related characteristics will have increased. It is known, in fact, that the returns to schooling in Vietnam's formal wage sector doubled between 1993 and 1998 (Gallup 2003), and it seems likely that the Doi Moi reforms will have increased the returns to other dimensions of human capital, including health.

\section{Methods}

Our interest is in assessing the impacts of (logarithmic) changes in health, $\Delta \ln h$, on logarithmic changes in income, $\Delta \ln Y$, medical consumption, $\Delta \ln M$, and non-medical consumption, $\Delta \ln C$. We use a fixed-effects specification similar to that used by Gertler and 
Gruber (2002), where (logarithmic) changes in the variable of interest, $\Delta \ln Z$ ( $Z$ alternately being $Y, M$ and $C$ ), are regressed on $\Delta \ln h$, community fixed effects, and a vector of household controls:

$$
\Delta \ln Z_{i j}=\alpha_{j}+\beta \Delta \ln h_{i j}+\sum_{k} \gamma_{k} X_{i j k}+\varepsilon_{i j} .
$$

Here $i$ indexes households, $j$ their communities, and the $\alpha$ 's are the community fixed effects, defined in the empirical analysis at the commune level rather than at the village level. Eqn (1) sweeps out time-invariant observable and unobservable variables that influence the levels of $Z$, but not unobservable influences on changes in it. Insofar as these influences vary only across communities, they will be captured by the community fixed effects. The household controls include average age in the household, its square and cube, and changes in household size (and the square and cube of these changes).

The interest is in the size of the coefficient $\beta$. A value of $\beta$ equal to zero in the income equation would indicate that health shocks do not impact on income, while zero values of $\beta$ in the medical and non-medical consumption equations respectively would indicate that people are fully insured against the medical costs associated with a health shock, and can fully smooth consumption in the face of health shocks or have otherwise been able to fully insure their nonmedical consumption against health shocks.

In addition to eqn (1), a second equation is estimated allowing the $\alpha$ 's and $\beta$ to vary with insurance status, $I$, and the household's income. Interacting $\Delta \ln h$ with $I$ allows us to test the hypothesis that the insured are better protected from health shocks. Income in the interactions is captured by a dummy, $P$, indicating whether the household was in the bottom $40 \%$ of the income distribution in the initial year, referred to below as a 'poor' household. ${ }^{2}$ The second equation estimated is thus:

$$
\Delta \ln Z_{i j}=\alpha_{j}+\beta \Delta \ln h_{i j}+\sum_{k} \gamma_{k} X_{i j k}+\delta I_{i j}+\phi I_{i j} \Delta \ln h_{i j}+\varphi P_{i j}+\tau P_{i j} \Delta \ln h_{i j}+\varepsilon_{i j},
$$

where $I$ and $P$ are allowed to influence the rate of change of $Z$ directly as well as through their interactions with $\Delta \ln h$.

As an alternative to eqns (2) and (3), a set of reduced-form equations have also been estimated, along the lines:

$$
\begin{aligned}
& \Delta \ln h_{i j}=\alpha_{1 j}+\sum_{k} \gamma_{1 k} X_{i j k}+\varepsilon_{1 i j} \\
& \Delta \ln Y_{i j}=\alpha_{2 j}+\sum_{k} \gamma_{2 k} X_{i j k}+\varepsilon_{2 i j} \\
& \Delta \ln C_{i j}=\alpha_{3 j}+\sum_{k} \gamma_{3 k} X_{i j k}+\varepsilon_{3 i j} \\
& \Delta \ln M_{i j}=\alpha_{4 j}+\sum_{k} \gamma_{4 k} X_{i j k}+\varepsilon_{4 i j}
\end{aligned}
$$

and smoothing is assessed through an examination of the correlations among the residuals. This is broadly the approach used by Blundell et al. (2004) in their analysis of income shocks and consumption. The first equation can be thought of as a stochastic version of a dynamic health

\footnotetext{
${ }^{2}$ In fact, closer to $60 \%$ of the population was poor in Vietnam in 1992/93 (Glewwe 2003).
} 
demand equation in Grossman's (1972) model. The evolution of health capital over time reflects the time profiles of the depreciation rate and any other time-varying variables, but also the size of any random 'shocks'. The latter, which are captured by $\varepsilon_{1}$, could be rationalized in terms of the depreciation rate being stochastic rather than deterministic as in Grossman's original formulation (cf. Grossman 2000). Correlations between estimates of $\varepsilon_{1}$ and the other residuals provides information on the extent to which health shocks get transmitted into unexpected changes in income, and medical and non-medical consumption.

$\underline{\text { Data }}$

The data are from the two-wave Vietnam Living Standards Survey (VLSS). A representative sample of 4800 households was interviewed in 1992/93, and then again in $1997 / 98$.

The focus is on changes in adult health, measured by the body mass index (BMI). This is equal to the individual's weight in kilograms divided by the square of the individual's height in meters. BMI is first and foremost a measure of nutrition. A person with a BMI score below 18.5 is considered 'underweight', while someone with a BMI score in the range 18.5-24.9 is considered 'normal'. An individual with a BMI score in the range 25-29.9 is considered to be 'overweight', and someone with a score higher than 30 is considered obese. In Vietnam in the survey period, less than $1 \%$ of the sample in either year was classified as overweight or obese, while roughly a quarter of the sample were classified as underweight. While primarily a measure of nutritional status, BMI has been found to be a good predictor of mortality, with mortality risk higher at both the bottom and top ends of the scale (Calle, Thun et al. 1999). Account is taken below of the non-monotonic relationship between health and BMI. Beyond BMI, the VLSS contains very little by way of useful information on adult health. Respondents were asked whether they had been sick in the four weeks prior to the interview on both occasions, but the question was posed differently in the two waves, so comparisons across the waves are not possible. In any case, evidence from the work of Gertler and Gruber (2002) suggests that changes in a short-term and self-reported health measure such as illness in the previous four weeks is unlikely to be associated with income and consumption changes. Indeed, a key conclusion of their work is that any failure to smooth consumption in response to health shocks is likely to be in relation to objective long-term health measures, not short-term subjective measures. Their measure-an index of people's ability to perform activities of daily living - is not available in the VLSS. BMI seems, however, a good substitute. Indeed, it may be potentially a good complement.

Income is total per capita household income, broken down into earned income (wage income as well as income from agriculture and any family business) and unearned income (gifts, remittances, pensions, and the like). Medical spending is per capita household medical outlays, excluding health insurance contributions, based on a 12-month reference period. Non-medical consumption is broken down into food consumption and non-food consumption, the latter including the use value of durables. ${ }^{3}$

\footnotetext{
${ }^{3}$ Full details are available in the VLSS basic information document available at http://www.worldbank.org/lsms/country/vn98/vn98bif.pdf.
} 
A household is classified as 'insured' if any adult member is covered by the VHI scheme. Because almost all of the voluntary members are school children, this means that the insurance variable captures compulsory rather than voluntary insurance. This is easily defended as exogenous ${ }^{4}$ and avoids the difficulty of heterogeneous coverage across the compulsory and voluntary schemes. By defining a household as covered if any adult member is insured does not capture the fact that some households have more than one member covered. Alternative more precise definitions would, however, make the results harder to interpret. The income-poverty variable, $P$, is defined as one if the household is in the poorest $40 \%$ of the $1992 / 93$ total per capita income distribution.

Table 1 provides some key descriptive statistics. The BMI variable is the change in the logarithm of the BMI average across all adult household members-alternative definitions are discussed and used below. On average, household average BMI has increased between 1993 and 1998, but there is considerable variation, with many households $(N=1779)$ experiencing reductions in average household BMI. Income and consumption growth were strong in Vietnam over the period in question. Medical consumption, by contrast, grew more modestly, and unsurprisingly food consumption grew more slowly than non-food consumption. Variations across households-including negative growth-are evident in income, medical consumption and non-medical consumption.

Table 1: Descriptive statistics

\begin{tabular}{|c|c|c|c|c|c|}
\hline Variable & $\begin{array}{c}\text { No. } \\
\text { Households } \\
\text { in sample }\end{array}$ & Mean & $\begin{array}{l}\text { Std. } \\
\text { Dev. }\end{array}$ & Minimum & $\begin{array}{l}\text { Maximu } \\
\mathrm{m}\end{array}$ \\
\hline$\Delta h$ : logarithmic change in BMI & 4295 & 0.014 & 0.067 & -0.350 & 0.424 \\
\hline$\Delta Y$ : logarithmic change in total income & 4227 & 0.446 & 0.928 & -5.863 & 6.171 \\
\hline $\begin{array}{l}\Delta Y \text { : logarithmic change in unearned } \\
\text { income }\end{array}$ & 3335 & 0.612 & 1.859 & -7.337 & 8.017 \\
\hline $\begin{array}{l}\Delta Y \text { : logarithmic change in earned } \\
\text { income }\end{array}$ & 4077 & 0.369 & 1.044 & -6.524 & 8.259 \\
\hline $\begin{array}{l}\Delta M \text { : logarithmic change in medical } \\
\text { consumption }\end{array}$ & 4075 & 0.111 & 1.498 & -5.259 & 5.976 \\
\hline $\begin{array}{l}\Delta C \text { : logarithmic change in non-medical } \\
\text { consumption }\end{array}$ & 4302 & 0.211 & 0.451 & -1.961 & 2.239 \\
\hline $\begin{array}{l}\Delta C: \text { logarithmic change in food } \\
\text { consumption }\end{array}$ & 4302 & 0.061 & 0.455 & -1.827 & 2.240 \\
\hline $\begin{array}{l}\Delta C: \text { logarithmic change in non-food } \\
\text { consumption } \\
I: \text { household has at least one member }\end{array}$ & 4292 & 0.250 & 0.671 & -2.597 & 4.482 \\
\hline with health insurance in 1998 & 4303 & 0.266 & 0.442 & 0.000 & 1.000 \\
\hline
\end{tabular}

${ }^{4}$ Due to the way school children are enrolled en masse, the term 'voluntarily' is actually a bit of a misnomer. 


\section{MAIN RESULTS}

\section{$\underline{B M I}$ changes and income changes}

The results in Table 2 show that household average changes in BMI are positively and significantly associated with changes in total per capita household income. On the face of it, this is evidence of BMI shocks leading to reductions-and substantial reductions at that-in household income. This association may, however, reflect reverse causality-idiosyncratic income shocks feeding back to BMI. Several pieces of evidence together suggest, however, that this could only be a part of the explanation of the association.

Table 2: Effects of changes in BMI on changes in income and medical spending

\begin{tabular}{lccc}
\hline & $\begin{array}{c}(1) \\
\text { Change in total } \\
\text { income }\end{array}$ & $\begin{array}{c}(2) \\
\text { Change in } \\
\text { unearned income }\end{array}$ & $\begin{array}{c}(3) \\
\text { Change in } \\
\text { earned income }\end{array}$ \\
\hline Change in average BMI among household & 0.912 & -0.675 & 1.262 \\
members aged 18+ in 1992/93 & $(3.94)$ & $(1.40)$ & $(4.34)$ \\
Average age of all household members & 0.005 & 0.031 & 0.004 \\
1992 & $(0.30)$ & $(0.86)$ & $(0.18)$ \\
Average age squared & 0.000 & -0.001 & 0.000 \\
& $(0.59)$ & $(0.80)$ & $(0.53)$ \\
Average age cubed & 0.000 & 0.000 & 0.000 \\
Change in household size & $(0.8)$ & $(0.78)$ & $(0.59)$ \\
& -0.079 & -0.245 & -0.019 \\
Change in household size squared & $(7.91)$ & $(11.34)$ & $(1.54)$ \\
Change in household size cubed & -0.005 & 0.008 & -0.004 \\
& $(2.14)$ & $(1.53)$ & $(1.31)$ \\
Intercept & 0.000 & 0.001 & 0.000 \\
& $(0.31)$ & $(3.04)$ & $(0.44)$ \\
& 0.409 & 0.164 & 0.436 \\
\end{tabular}

Note: $t$-statistics in parentheses. Equation also includes commune-level fixed effects, which were jointly significant.

First, recent evidence suggests that income changes have had at best a small effect on child malnutrition in Vietnam in the period in question (Glewwe, Koch et al. 2003). Most of the instrumental variables (IV) cross-section estimates of the impact of household consumption on child malnutrition reported by Glewwe et al. are statistically insignificant, and all of their paneldata estimates are insignificant. Their estimates are also small, all of which leads them to conclude that economic growth has been responsible for only a small part of the rapid improvement in child nutrition in Vietnam during the 1990s. These results refer, of course, to child nutrition, not adult BMI. However, the case for believing that OLS regressions of malnutrition on household income or consumption suffer from simultaneity bias is typically considered to be even stronger in the case of adult BMI than child malnutrition (Alderman 2000) - it is not a question of household members adjusting their labor supply to care for sick children or being able to buy more medical care for them; rather the link is more direct, with adults themselves falling sick and having to reduce hours or working less productively. This refers to the size of any bias, of course, and it is possible that even after correcting for it, the impact of income on adult nutrition in Vietnam in this period has been appreciable even if its 
impact on child nutrition does not appear to have been. It is not obvious, though, why this should be the case.

Second, the reverse causality interpretation of the association between changes in BMI and changes in total income is hard to square with columns 2 and 3 of Table 2. These show that while changes in earned income are positively associated with BMI changes, changes in unearned income are negatively associated with them. Economic theory (Grossman 1972) predicts that changes in earned and unearned income will alter the demand for health, but that while changes in earned income (or, more exactly, the wage rate) may cause a reduction in the demand for health, the effect of a rise in unearned income ought to be unambiguously nonnegative. ${ }^{5}$ The signs are therefore contrary to what theory predicts if it is indeed income changes that are driving health changes. A more plausible explanation of the negative coefficient in column 2 is that as BMI falls, the household receives additional gifts, remittances, etc. from concerned friends and relatives_-an issue explored further below.

Table 3 presents the third piece of evidence in favor of the argument that it is primarily BMI changes leading to income changes rather than vice versa. Instead of including a variable capturing household average BMI change, Table 2 includes separate variables for the BMI change of the household head and for the BMI change of the spouse. The correlation between these two variables is just 0.091. The results in Table 2 show that the association between household average BMI changes and household income reflects entirely the association between changes in the BMI of the head of household and household income. This is consistent with BMI changes bringing about income changes if, as is likely, the household head plays a more important role in generating income than the spouse.

Table 3: Differential effects of BMI changes of household head and spouse

\begin{tabular}{lccc}
\hline & $\begin{array}{c}(1) \\
\text { Change in total } \\
\text { income }\end{array}$ & $\begin{array}{c}(2) \\
\text { Change in unearned } \\
\text { income }\end{array}$ & $\begin{array}{c}(3) \\
\text { Change in earned } \\
\text { income }\end{array}$ \\
\hline Change in BMI of household head & 0.683 & -0.256 & 0.818 \\
& $(2.71)$ & $(0.47)$ & $(2.55)$ \\
Change in BMI of household & -0.029 & -0.101 & -0.088 \\
head's spouse & $(0.14)$ & $(0.23)$ & $(0.33)$ \\
\hline
\end{tabular}

Note: $t$-statistics in parentheses. Regressions include all covariates listed in Table 2 and commune fixed effects, which were jointly significant.

One might object to the results in Tables 2 and 3 on the grounds that BMI is not, as was previously noted, monotonically increasing in good health. Table 4 shows the effects of transforming BMI into a monotonically-decreasing measure of health, using the mortality risks for the BMI ranges reported in Calle et al. (1999). The results are very similar, reflecting the very small numbers of overweight and obese Vietnamese in the 1990s. In what follows, BMI is left untransformed.

\footnotetext{
${ }^{5}$ In Grossman's 'pure consumption' model, a rise in the wage rate would result in a reduction in the demand for health if health were more time-intensive than household production generally. In his 'pure investment' model, the effect of a wage increase would be to raise the demand for health, unless time is the only input in the gross health investment production function, in which case a wage increase would leave the demand for health unaffected.
} 
Table 4: Effects of changes in BMI-based mortality risk on changes in income

\begin{tabular}{lccc}
\hline & $\begin{array}{c}(1) \\
\text { Change in total } \\
\text { income }\end{array}$ & $\begin{array}{c}(2) \\
\text { Change in } \\
\text { unearned income }\end{array}$ & $\begin{array}{c}(3) \\
\text { Change in } \\
\text { earned income }\end{array}$ \\
\hline Change in average BMI-based mortality risk among & -0.599 & 0.761 & -1.026 \\
household members aged 18+ in 1992/93 & $(1.91)$ & $(1.14)$ & $(2.61)$ \\
\hline
\end{tabular}

Note: t-statistics in parentheses. Regressions include all covariates listed in Table 2 and commune fixed effects, which were jointly significant.

Table 5 reports the estimates of eqn (2) which adds health insurance, the poverty dummy and their interactions with BMI changes. The interactions are insignificant-there appears to be no significant differences between the poor and non-poor or between the insured and uninsured in the effects of BMI changes on changes in either unearned and earned income.

Table 5: Differential effects of BMI changes on income by insurance status and income group

\begin{tabular}{lccc}
\hline & $\begin{array}{c}(1) \\
\text { Change in } \\
\text { total income }\end{array}$ & $\begin{array}{c}(2) \\
\text { Change in } \\
\text { unearned income }\end{array}$ & $\begin{array}{c}(3) \\
\text { Change in } \\
\text { earned income }\end{array}$ \\
\hline Health insurance & 0.223 & 0.324 & 0.147 \\
Change in average BMI among household & $(6.95)$ & $(4.05)$ & $(3.87)$ \\
members aged 18+ in 1992/93 & 0.653 & -1.066 & 0.803 \\
BMI x Health insurance & $(2.41)$ & $(1.51)$ & $(2.45)$ \\
Poor 1992/93 & 0.201 & 0.276 & 0.577 \\
& $(0.48)$ & $(0.27)$ & $(1.16)$ \\
BMI x Poor 1992/93 & 0.851 & 0.499 & 0.832 \\
& $(30.16)$ & $(6.96)$ & $(24.82)$ \\
Intercept & 0.009 & 0.740 & 0.420 \\
& $(0.02)$ & $(0.77)$ & $(0.90)$ \\
& -0.155 & -0.073 & -0.150 \\
\hline
\end{tabular}

Note: t-statistics in parentheses. Regressions include all covariates listed in Table 2 and commune fixed effects, which were jointly significant.

\section{BMI changes and changes in medical spending}

Beyond their impact on income, adverse health shocks are likely to necessitate increases in medical spending. Column 1 of Table 6 shows that adverse health events are associated with increases in medical spending. The size of the coefficient is similar in absolute terms to the size of the income coefficient. This contrasts with the results for Indonesia presented in Gertler and Gruber, where the income effect was much larger in absolute size than the medical spending effect. This may well reflect the different settings. In Vietnam, $80 \%$ of health spending is paid out of pocket, compared to $47 \%$ in Indonesia (World_Health_Organization 2000; World_Bank, SIDA et al. 2001). Furthermore, in the present sample in 1997, medical outlays accounted for $6 \%$ of non-medical consumption, which is substantially larger than the $1 \%$ figure reported by Gertler and Gruber. 
Table 6: Effects of BMI changes on medical consumption, by insurance status and income

\begin{tabular}{lccc}
\hline & $(1)$ & $(2)$ & $(3)$ \\
\hline Change in average BMI among household members & -0.968 & -1.197 & -0.700 \\
aged 18+ in 1992/93 & $(2.68)$ & $(2.87)$ & $(1.36)$ \\
Health insurance & & -0.206 & -0.194 \\
& & $(3.41)$ & $(3.20)$ \\
BMI x Health insurance & 1.036 & 0.835 \\
& & $(1.33)$ & $(1.06)$ \\
Poor 1992/93 & & 0.103 \\
BMI x Poor 1992/93 & & $(1.93)$ \\
& & & -1.182 \\
Estimates of BMI effects by insurance and income group & & & $(1.62)$ \\
Poor uninsured & & -1.882 \\
& & & $(-3.14)$ \\
Poor insured & & -1.047 \\
Non-poor uninsured & & $-1.20)$ \\
Non-poor insured & & -0.700 \\
& & & $(1.36)$ \\
\end{tabular}

Note: t-statistics in parentheses. Regressions include all covariates listed in Table 2 and commune fixed effects, which were jointly significant.

The results in column 1 of Table 6 are for the full sample. Columns 2 and 3 suggest some heterogeneity in impacts, although the coefficients on the interaction terms are not significant at conventional levels. The estimated coefficients by subgroup indicate that the largest increase in medical spending following an adverse BMI shock is among the poor uninsured, the only group for which the impact is significant. The fact that the insured face no increase in medical outlays following an adverse health event is consistent with the generous coverage of the VHI program during the time period under consideration.

\section{BMI changes and changes in food and non-food consumption}

Negative BMI shocks thus appear to be associated with reductions in household income and increases in medical spending, at least among poor uninsured households. The question arises: Can households hold their food and non-food consumption constant in the face of these changes? 
Table 7: Effects of BMI changes on food and non-food consumption

\begin{tabular}{|c|c|c|c|c|c|c|c|c|}
\hline & \multicolumn{4}{|c|}{ Food consumption } & \multicolumn{4}{|c|}{ Non-food consumption } \\
\hline & (1) & $(2)$ & (3) & (4) & (5) & (6) & (7) & (8) \\
\hline Change in average & 0.173 & 0.120 & 0.231 & 0.169 & 0.432 & 0.322 & 0.654 & 0.533 \\
\hline BMI among & $(1.83)$ & $(1.10)$ & $(1.98)$ & $(1.27)$ & $(3.03)$ & $(1.97)$ & $(3.70)$ & $(2.64)$ \\
\hline \multirow{2}{*}{\multicolumn{9}{|c|}{$\begin{array}{l}\text { household } \\
\text { members aged }\end{array}$}} \\
\hline & & & & & & & & \\
\hline \multicolumn{9}{|l|}{$18+$ in $1992 / 93$} \\
\hline \multirow[t]{2}{*}{ Health insurance } & & 0.013 & & 0.024 & & 0.070 & & 0.089 \\
\hline & & $(0.82)$ & & $(1.50)$ & & $(2.90)$ & & (3.73) \\
\hline BMI $x$ Health & & 0.186 & & 0.164 & & 0.335 & & 0.272 \\
\hline insurance & & $(0.90)$ & & $(0.80)$ & & $(1.08)$ & & $(0.88)$ \\
\hline \multirow[t]{2}{*}{ Poor 1992} & & & 0.116 & 0.118 & & & 0.178 & 0.186 \\
\hline & & & $(8.40)$ & $(8.51)$ & & & $(8.52)$ & $(8.85)$ \\
\hline \multirow{2}{*}{ BMI x Poor 1992} & & & -0.115 & -0.084 & & & -0.508 & -0.445 \\
\hline & & & $(0.62)$ & $(0.45)$ & & & $(1.81)$ & $(1.57)$ \\
\hline \multicolumn{9}{|l|}{ R-squared } \\
\hline \multirow{4}{*}{\multicolumn{9}{|c|}{$\begin{array}{l}\text { Estimates of BMI } \\
\text { effects by } \\
\text { insurance and } \\
\text { income group }\end{array}$}} \\
\hline & & & & & & & & \\
\hline & & & & & & & & \\
\hline & & & & & & & & \\
\hline \multirow[t]{2}{*}{ Poor uninsured } & & & & 0.085 & & & & 0.088 \\
\hline & & & & $(0.56)$ & & & & $(0.38)$ \\
\hline \multirow[t]{2}{*}{ Poor insured } & & & & 0.249 & & & & 0.360 \\
\hline & & & & $(1.10)$ & & & & (1.05) \\
\hline Non-poor & & & & 0.169 & & & & 0.533 \\
\hline uninsured & & & & $(1.27)$ & & & & (2.64) \\
\hline \multirow[t]{2}{*}{ Non-poor insured } & & & & 0.333 & & & & 0.805 \\
\hline & & & & $(1.83)$ & & & & $(2.91)$ \\
\hline
\end{tabular}

Note: $t$-statistics in parentheses. Regressions include all covariates listed in Table 2 and commune fixed effects, which were jointly significant. 
Columns 1 and 4 of Table 7 suggest that for the sample as a whole households are unable to smooth either food consumption or non-food consumption in the face of BMI shocks. Of the two, they are more successful at smoothing food consumption. There is some evidence here, then, for the claim that adverse health shocks in the developing world compromise people's ability to maintain adequate consumption levels, including consumption of foodstuffs.

Columns 2 and 5 suggest that, if anything, health insurance worsens households' ability to smooth non-medical consumption in the face of BMI shocks, although the coefficients are not significant. The fact that health insurance does nothing to increase households' ability to smooth non-medical consumption in the face of health shocks presumably reflects the fact that while health insurance takes care of any medical outlays following a BMI shock, it does nothing to tackle the income losses, which as was seen earlier are appreciable. The hint-and it is only a hint given the size of the relevant t-statistic - that health insurance may worsen households' ability to smooth consumption would be consistent with a story that relatives and friends are more likely to look favorably on a request for a loan following a health shock if the household does not have health insurance. They may take the view-wrongly, it seems, given the results presented here-that an insured household ought to be able to cope financially in the face of a health shock.

Columns 3 and 4 and 7 and 8 of Table 7 contain something of a surprise, namely that if anything, the poor are better protected than the non-poor from BMI shocks. The difference between the poor and non-poor is significant in the case of non-food consumption, though not in the case of food consumption. The implied coefficients from the model with both sets of interactions (columns 4 and 8) indicate that among poor households - whether insured or notthere is no impact of BMI shocks on either food consumption or non-food consumption. By contrast, among the better-off households, there is a significant effect of BMI shocks on both food and non-food consumption. This is counterintuitive, given that there are apparently no differences between the poor and better off in the income effects of BMI changes, and that the significant effects of BMI changes on medical spending noted earlier were specifically for the poor. The implication is that the poor are borrowing or dissaving to hold food and non-food consumption constant in the face of increased medical spending, presumably considerably so. The puzzle is why they rely exclusively on borrowing and dissaving and do not instead change their food and non-food consumption as the better off do. Possible explanations might include greater access by the poor to informal credit (not implausible but not especially likely either), or the existence of a threshold effect whereby poor households have levels of food and non-food consumption that are simply too low relative to basic needs to enable them to cut back in the face of an adverse BMI shock.

\section{REDUCED-FORM RESULTS}

This section reports results of the alternative approach to assessing the impacts of health shocks through an analysis of the correlations of the residuals of the reduced-form equations in eqn (3). Table 8 reports the coefficients of the reduced-form regressions for the full-sample and Table 9 the corresponding residual correlation matrix. The system of reduced-form regressions was then re-estimated for two sub-samples: the poorest $40 \%$ without health insurance, and the richest $60 \%$ with health insurance. 
Table 9 tells much the same story as Tables 2, 6 and 7. Unexplained changes in BMI are positively and significantly associated with (unexplained) changes in earned income, unexplained changes in BMI are not significantly associated with (unexplained) changes in unearned income. (At the 15\% level the latter association is significant and is negative-which echoes the finding vis-à-vis unearned income in Table 2.) BMI shocks are significantly and negatively associated with (unexplained) changes in medical spending, significantly and positively associated with (unexplained) changes in non-food consumption, but not significantly associated with (unexplained) changes in food consumption.

The residual correlations in Tables 10 and 11 are also consistent with the earlier results. For the poorest $40 \%$ without insurance, BMI shocks are significantly and negatively associated with (unexplained) changes in medical spending, but the residuals of the BMI and medical spending equations are not significantly correlated among the richest $60 \%$ of households with health insurance. Among the poorest $40 \%$ without health insurance, BMI shocks are not significantly associated with (unexplained) changes in either food or non-food consumption, while the residuals between the BMI equation and the non-food consumption equation are significantly correlated in the case of the richest $60 \%$ with health insurance.

The correlations between the residuals of the BMI reduced-form equation and the residuals of the other equations thus tell a similar story to the story that emerged from the previous section. The other correlations in Tables 9-11 also convey information about the impact of income shocks on medical and non-medical consumption. Income shocks-whether in earned or unearned income-are significantly and positively associated with (unexplained) changes in both food and non-food consumption, suggesting incomplete smoothing of consumption in the face of income shocks. The residual correlations also point to income shocks leading to changes in medical consumption. 
Table 8: Reduced-form growth equations for BMI, income, medical spending and non-medical consumption-full sample

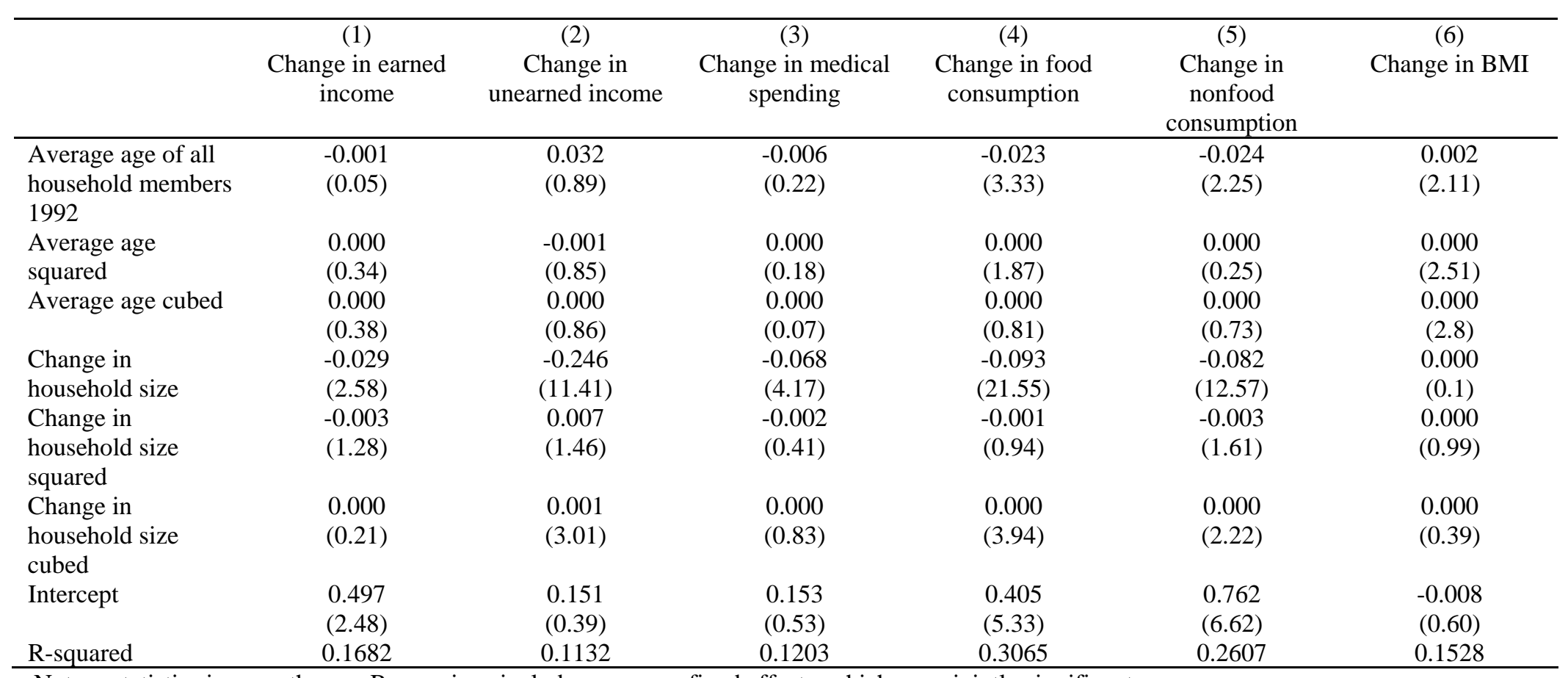

Note: $t$-statistics in parentheses. Regressions include commune fixed effects, which were jointly significant. 
Table 9: Correlation matrix of residuals from reduced-form growth equations-full sample

\begin{tabular}{|c|c|c|c|c|c|c|}
\hline & $\begin{array}{c}\text { (1) } \\
\text { Change in earned } \\
\text { income } \\
\end{array}$ & $\begin{array}{c}\text { (2) } \\
\text { Change in } \\
\text { unearned income }\end{array}$ & $\begin{array}{c}\text { (3) } \\
\text { Change in medical } \\
\text { spending }\end{array}$ & $\begin{array}{c}\text { (4) } \\
\text { Change in food } \\
\text { consumption }\end{array}$ & $\begin{array}{c}\text { (5) } \\
\text { Change in nonfood } \\
\text { consumption }\end{array}$ & $\begin{array}{c}\text { (6) } \\
\text { Change in BMI }\end{array}$ \\
\hline Change in earned income & 1.000 & & & & & \\
\hline Change in unearned income & $\begin{array}{c}-0.024 \\
0.174\end{array}$ & 1.000 & & & & \\
\hline Change in medical spending & $\begin{array}{l}-0.029 \\
0.073\end{array}$ & $\begin{array}{l}0.054 \\
0.002\end{array}$ & 1.000 & & & \\
\hline Change in food consumption & $\begin{array}{l}0.201 \\
0.000\end{array}$ & $\begin{array}{l}0.116 \\
0.000\end{array}$ & $\begin{array}{l}0.045 \\
0.004\end{array}$ & 1.000 & & \\
\hline $\begin{array}{l}\text { Change in nonfood } \\
\text { consumption }\end{array}$ & $\begin{array}{l}0.135 \\
0.000\end{array}$ & $\begin{array}{l}0.147 \\
0.000\end{array}$ & $\begin{array}{l}0.063 \\
0.000\end{array}$ & $\begin{array}{l}0.337 \\
0.000\end{array}$ & 1.000 & \\
\hline Change in BMI & $\begin{array}{l}0.064 \\
0.000\end{array}$ & $\begin{array}{c}-0.025 \\
0.154\end{array}$ & $\begin{array}{c}-0.043 \\
0.007\end{array}$ & $\begin{array}{l}0.029 \\
0.062\end{array}$ & $\begin{array}{l}0.047 \\
0.002\end{array}$ & 1.000 \\
\hline
\end{tabular}

Note: Prob values below correlations 
Table 10: Correlation matrix of residuals from reduced-form growth equations-poorest $40 \%$ of households without health insurance

\begin{tabular}{|c|c|c|c|c|c|c|}
\hline & $\begin{array}{c}(1) \\
\text { Change in earned } \\
\text { income }\end{array}$ & $\begin{array}{c}(2) \\
\text { Change in } \\
\text { unearned income }\end{array}$ & $\begin{array}{c}\text { (3) } \\
\text { Change in medical } \\
\text { spending }\end{array}$ & $\begin{array}{l}(4) \\
\text { Change in food } \\
\text { consumption }\end{array}$ & $\begin{array}{c}(5) \\
\text { Change in nonfood } \\
\text { consumption }\end{array}$ & $\begin{array}{c}\text { (6) } \\
\text { Change in BMI }\end{array}$ \\
\hline Change in earned income & 1.000 & & & & & \\
\hline Change in unearned income & $\begin{array}{c}-0.064 \\
0.049\end{array}$ & 1.000 & & & & \\
\hline Change in medical spending & $\begin{array}{l}-0.030 \\
0.302\end{array}$ & $\begin{array}{l}0.024 \\
0.449\end{array}$ & 1.000 & & & \\
\hline $\begin{array}{l}\text { Change in food } \\
\text { consumption }\end{array}$ & $\begin{array}{l}0.161 \\
0.000\end{array}$ & $\begin{array}{l}0.121 \\
0.000\end{array}$ & $\begin{array}{l}0.065 \\
0.018\end{array}$ & 1.000 & & \\
\hline $\begin{array}{l}\text { Change in nonfood } \\
\text { consumption }\end{array}$ & $\begin{array}{l}0.045 \\
0.109\end{array}$ & $\begin{array}{l}0.090 \\
0.004\end{array}$ & $\begin{array}{l}0.069 \\
0.012\end{array}$ & $\begin{array}{l}0.361 \\
0.000\end{array}$ & 1.000 & \\
\hline Change in BMI & $\begin{array}{l}0.065 \\
0.020\end{array}$ & $\begin{array}{l}-0.033 \\
0.292 \\
\end{array}$ & $\begin{array}{l}-0.067 \\
0.015 \\
\end{array}$ & $\begin{array}{l}0.002 \\
0.933\end{array}$ & $\begin{array}{c}-0.011 \\
0.671\end{array}$ & 1.000 \\
\hline
\end{tabular}

Note: Prob values below correlations 
Table 11: Correlation matrix of residuals from reduced-form growth equations_richest 60\% of households with health insurance

\begin{tabular}{|c|c|c|c|c|c|c|}
\hline & $\begin{array}{l}\text { (1) } \\
\text { Change in earned } \\
\text { income }\end{array}$ & $\begin{array}{c}\text { (2) } \\
\text { Change in } \\
\text { unearned income }\end{array}$ & $\begin{array}{l}\text { (3) } \\
\text { Change in medical } \\
\text { spending }\end{array}$ & $\begin{array}{l}\text { (4) } \\
\text { Change in food } \\
\text { consumption }\end{array}$ & $\begin{array}{l}\text { (5) } \\
\text { Change in nonfood } \\
\text { consumption }\end{array}$ & $\begin{array}{c}\text { (6) } \\
\text { Change in BMI }\end{array}$ \\
\hline Change in earned income & 1.000 & & & & & \\
\hline Change in unearned income & $\begin{array}{c}-0.074 \\
0.050\end{array}$ & 1.000 & & & & \\
\hline Change in medical spending & $\begin{array}{c}-0.019 \\
0.592\end{array}$ & $\begin{array}{l}0.187 \\
0.000\end{array}$ & 1.000 & & & \\
\hline Change in food consumption & $\begin{array}{l}0.261 \\
0.000\end{array}$ & $\begin{array}{l}0.022 \\
0.557\end{array}$ & $\begin{array}{c}-0.001 \\
0.989\end{array}$ & 1.000 & & \\
\hline $\begin{array}{l}\text { Change in nonfood } \\
\text { consumption }\end{array}$ & $\begin{array}{l}0.216 \\
0.000\end{array}$ & $\begin{array}{l}0.155 \\
0.000\end{array}$ & $\begin{array}{l}0.033 \\
0.347\end{array}$ & $\begin{array}{l}0.310 \\
0.000\end{array}$ & 1.000 & \\
\hline Change in BMI & $\begin{array}{l}0.117 \\
0.001\end{array}$ & $\begin{array}{c}-0.015 \\
0.684\end{array}$ & $\begin{array}{c}-0.009 \\
0.806\end{array}$ & $\begin{array}{l}0.050 \\
0.152\end{array}$ & $\begin{array}{l}0.088 \\
0.011\end{array}$ & 1.000 \\
\hline
\end{tabular}

Note: Prob values below correlations 


\section{CONCLUSIONS}

While there is a great deal of anecdotal evidence on the economic impacts of adverse health shocks, there is relatively little hard empirical evidence. This paper builds on recent empirical work to explore in the context of post-reform Vietnam two related issues: how far household income and medical care spending respond to health shocks; and how far household consumption is protected against health shocks.

The results suggest that adverse health shocks - captured by negative changes in body mass index (BMI) - are associated with reductions in earned income. This appears to be only partly —if at all_-due to a reverse feedback from income changes to BMI changes. By contrast, there is a hint - the relevant coefficient is not significant-that adverse BMI shocks may result in increases in unearned income. This may reflect additional gifts, remittances, etc. from family and friends following the health shock. Medical spending is found to increase following an adverse health shock, but not among those with health insurance. The impact for the uninsured is large, equal in absolute size to the income loss associated with a BMI shock. This contrasts with previous work on Indonesia and reflects the heavy emphasis in Vietnam on out-of-pocket expenditures, which accounted for $80 \%$ of total health spending in 1998 . The lack of impact for the insured points to complete insurance against the medical care costs associated with health shocks, and is consistent with the very generous coverage of Vietnam's health insurance program in this period.

Adverse health shocks appear, then, to cause reductions in total household income and increases in medical spending, at least among the uninsured. The issue arises: have Vietnamese households been able to hold their food and non-food consumption constant in the face of these income reductions and extra medical care outlays? The results suggest not. For the sample as a whole, both food and non-food consumption are found to be responsive to health shocks, indicating an inability to smooth non-medical consumption in the face of health shocks. Reassuringly and not altogether surprisingly, food consumption comes closer to being smoothed than non-food consumption. Further analysis reveals some interesting differences across different groups within the sample. Households with insurance come no closer to smoothing non-medical consumption than uninsured households; indeed, there is a hint - the coefficient is not significant-that they do worse. The fact they do no better reflects the focus of health insurance on the medical expenses associated with health shocks to the complete exclusion of the income losses. Finally, and somewhat counterintuitively, better-off households-including insured households-fare worse than poorer households in smoothing their non-medical consumption in the face of health shocks, despite the fact that in the case of insured households there are no medical bills associated with an adverse health event. Why the poor rely on dissaving and borrowing to such an extent, and do not apparently reduce their food and non-food consumption following an adverse health shock as the better off do, is a puzzle. One possibility is the existence of a threshold effect whereby poor households have levels of food and non-food consumption that are simply too low relative to basic needs to enable them to cut back in the face of an adverse BMI shock. 


\section{References}

Alderman, H. (2000). Anthropometry. Designing Household Survey Questionnaires for Developing Countries. M. Grosh and P. Glewwe. Washington DC, The World Bank. 1: 251-272.

Bloom, G. (1998). "Primary health care meets the market in China and Vietnam." Health Policy 44(3): 233-52.

Blundell, R., L. Pistaferri, et al. (2004). Consumption inequality and partial insurance. London, Institute for Fiscal Studies.

Calle, E. E., M. J. Thun, et al. (1999). "Body-mass index and mortality in a prospective cohort of U.S. adults." N Engl J Med 341(15): 1097-105.

Dercon, S. and P. Krishnan (2000). "In Sickness and in Health: Risk Sharing within Households in Rural Ethiopia." Journal of Political Economy 108(4): 688-727.

Gallup, J. (2003). The wage labor market and inequality in Vietnam. Economic Growth, Poverty and Household Welfare: Policy Lessons from Vietnam. P. Glewwe, N. Agrawal and D. Dollar. Washington DC, World Bank.

Gertler, P. and J. Gruber (2002). "Insuring consumption against illness." American Economic Review 92(1): 51-76.

Glewwe, P. (2003). An overview of economic growth and household welfare in Vietnam in the 1990s. Economic Growth, Poverty and Household Welfare: Policy Lessons from Vietnam. P. Glewwe, N. Agrawal and D. Dollar. Washington DC, World Bank.

Glewwe, P., S. Koch, et al. (2003). Childnutrition, economic growth, and the provision of health services in Vietnam. Economic Growth, Poverty and Household Welfare: Policy Lessons from Vietnam. P. Glewwe, N. Agrawal and D. Dollar. Washington DC, World Bank.

Grossman, M. (1972). The Demand for Health: A Theoretical and Empirical Investigation. New York, NBER.

Grossman, M. (2000). The human capital model. North Holland Handbook in Health Economics. A. Culyer and J. Newhouse. Amsterdam, Netherlands, North Holland: 1804-1862.

Jalan, J. and M. Ravallion (1999). "Are the Poor Less Well Insured? Evidence on Vulnerability to Income Risk in Rural China." Journal of Development Economics 58(1): 61-81.

Narayan, D., R. Patel, et al. (2000). Voices of the Poor: Can Anyone Hear Us? New York, N.Y., Oxford University Press.

Townsend, R. M. (1994). "Risk and Insurance in Village India." Econometrica 62(3): 539-91.

Townsend, R. M. (1995). "Consumption Insurance: An Evaluation of Risk-Bearing Systems in Low-Income Economies." Journal of Economic Perspectives 9(3): 83-102.

Wagstaff, A. and E. van Doorslaer (2003). "Catastrophe and impoverishment in paying for health care: with applications to Vietnam 1993-98." Health Econ 12(11).

World_Bank, SIDA, et al. (2001). Vietnam. Growing Healthy: A Review of Vietnam's Health Sector. Hanoi, The World Bank.

World_Health_Organization (2000). The World Health Report 2000. Health Systems: Improving Performance. Geneva, The World Health Organization.

hsladovich

M:IPS\PS Document Library (2001-2005)।Working Papers\wagstaff\0-3181.final.doc

06/02/2005 10:24:00 AM 